UDC 65.012.32:331

DOI: 10.15587/2706-5448.2022.251947

Article type «Reports on Research Projects»

\section{Sergey Goolak, Eduard Yermolenko, Viktor Tkachenko, Svitlana Sapronova, Viktor Yurchenko}

\title{
DETERMINATION OF VOLTAGE AT THE RECTIFIER INSTALLATION OF THE ELECTRIC LOCOMOTIVE VL-80K FOR EACH POSITION OF THE CONTROLLER DRIVER'S
}

The object of research is the electrical processes in the control system of the traction drive of the electric locomotive VL-80K (Russia). To improve the accuracy of its mathematical model, it is necessary to use the values of the parameters determined during experimental studies of the traction drive control system. In particular, it is important to use in the traction drive model the value of the voltages on the arms of the rectifier installation of the electric locomotive, taking into account the position of the driver's controller. The complexity of the simulation lies in the fact that the reference does not provide the value of the voltage on the arms of the rectifier for each position of the driver's controller, which makes it difficult to verify the resulting model. A scheme for measuring the voltage value on the arms of the rectifier installation of an electric locomotive for each position of the position of the driver's controller is proposed. On its basis, a simulation model is developed in the MATLAB software environment. The simulation model implements an algorithm for closing the contactors of the electric group contactor for each position of the position of the driver's controller. Approbation of the voltage measurement technique was carried out on an electric locomotive of the VL-80K series during a trip on the Darnytsia - Myronivka section (Ukraine). Comparison of the voltage values on the arms of the rectifier installation, obtained experimentally, with the passport data showed that the measurement error was $0.5 \%$. In addition, the experimental results showed that the voltages on the arms of the rectifier for paired positions of the position of the driver's controller are the same, for odd ones they are different. Therefore, when simulating the operation of the traction drive control system, the voltage values on different arms of the rectifier installation were taken separately. Comparison of the simulation results for the nominal mode with passport data showed that for this mode the measurement error was $3.78 \%$. For all others, it did not exceed $5 \%$.

Keywords: traction drive, control system, electric contactor, voltage value, rectifier installation.

\section{How to cite}

Goolak, S., Yermolenko, E., Tkachenko, V., Sapronova, S., Yurchenko, V. (2022). Determination of voltage at the rectifier installation of the electric locomotive VL-80K for each position of the controller driver's. Technology Audit and Production Reserves, 1 (1 (63)), 23-29. doi: http://doi.org/10.15587/ 2706-5448.2022.251947

\section{Introduction}

The study of dynamic processes in the traction drive of electric locomotives requires the construction of an adequate drive model, through which it would be possible to determine certain characteristics of the drive with a high degree of certainty [1]. The traction drive system for electric locomotives of the VL-80T (Russia), VL-80K (Russia), ChS-4 (Czech Republic), ChS-8 (Czech Republic) series consists of pulsating current traction motors, a traction transformer, a group electrical contactor, a rectifier installation and a mechanical parts.

When modeling such a traction drive, a number of difficulties arise. These difficulties can be seen from the analysis of the work [2], in which a model of the traction drive of the VL-80K electric locomotive is proposed. In developing the model, the following conjectures were proposed:

- armature winding inductance is a constant value;

- magnetic losses in the engine steel are not taken into account;

- losses from the action of eddy currents are not taken into account;

- mechanical part of the drive is not connected;

- model works on one fixed position of the train.

Studies [3-5] show that the excitation winding inductance is a function of the excitation current, and the armature winding inductance is a function of the armature current. Moreover, these dependencies are non-linear. Not taking into account these dependencies is incorrect and will lead to an error in determining the parameters in the 
simulation. Despite the obviously correct approach to taking into account the non-linear nature of the configuration of the values of the indicated inductances when the corresponding currents change, magnetic losses in the motor steel were not taken into account in $[4,5]$.

Approaches to taking into account magnetic losses in the steel of a traction motor can be found in studies [6-8]. So, in the study [7], a method for determining magnetic losses in the steel of a traction motor was proposed and it was shown that magnetic losses became functions of the motor shaft speed.

The implementation of the traction motor model, taking into account the nonlinear nature of the change in the values of the inductance of the armature and excitation windings from changes in the corresponding currents and taking into account magnetic losses in the motor steel, is given in the study [9]. But even in this study, losses in the traction motor from the action of eddy currents are not taken into account.

Accounting for the effect of eddy currents when modeling a pulsating current traction motor can be found in [10-12], but these works do not take into account magnetic losses in the steel of the traction motor.

In [2], the mechanical part of the traction drive is not connected. This factor is not important for solving the problems posed in [2]. But when it is necessary to take into account the electromechanical processes in the traction drive, the influence of the track profile, the result of the interaction of the wheel with the rack, the mechanical part should be present in the mathematical model [13-15].

An integral part of the traction drive is the control system. In a number of $\mathrm{AC}$ electric locomotives, the so-called step or contactor-rheostat system is used as a control system. Such control systems are used on electric locomotives of the VL-80T, VL-80K, ChS-4, ChS-8 series. In electric locomotives of the VL-80K series, the traction transformer is structurally a transformer consisting of a primary and two secondary traction windings. Each traction winding consists of an unregulated and an adjustable part. The non-adjustable part has four sections. The regulated sections are connected to the rectifier installation by closing the corresponding contactors of the group electrical contactor (GEC). The rectifier installation of the electric locomotive has two sections. Two traction motors are connected to each section [16]. The signal to connect one or another section of the secondary winding of the traction transformer enters the GEC from the driver's controller. In the GEC, depending on the position of the driver's controller, the corresponding GEC contactors are closed according to a fixed algorithm. The question arises of the task on the model of the traction drive of the electric locomotive of the indicated series of the intensity of the change in speed.

On electric locomotives with asynchronous traction motors, control systems with direct torque control [17] and vector control $[18,19]$ are used. In the starting mode, the intensity of the speed change is set taking into account the conditions of the traction problem [20-22]. In the braking mode, the intensity of the speed change is set taking into account the conditions of the braking problem [23-25]. In both cases, the intensity of the speed change is set as a separate program block. To study the electromechanical processes in the traction drive of the VL- $80 \mathrm{~K}$ electric locomotive in various operating modes of the electric locomotive, it is necessary to develop a control system with a program generator of the speed change intensity.

Thus, determining the voltages at the rectifier installation of the VL-80K electric locomotive for each position of the driver's controller is an urgent task. The object of research is the electrical processes in the control system of the traction drive of the electric locomotive VL-80K. The aim of research is to determine the inductances of the pulsating current traction motor as a function of the armature current.

\section{Research methodology}

The research is based, on the one hand, on measuring the voltages on the arms of the rectifier for each position of the driver's controller (Fig. 1), and on the other hand, on the result of modeling the control system of the traction drive of an electric locomotive. The simulation model of the control system is based on the circuit diagram (Fig. 1) and the GEC contactor switching algorithm (Table 1) [26] in the MATLAB software environment (Fig. 2).

The model consists of a traction transformer «Traction transformer», GEC «Group electrical contactor», a voltage source $\langle U c »$, a block that sets the position of the driver's controller $\langle p »$, voltmeters and an oscilloscope. The model is implemented in the Simulink application of the MATLAB software environment. The traction transformer and the power part of the GEC are implemented using elements of the Simscape library of the Specialized Power System section. The traction transformer is organized using the Multi-Winding Transformer element. Its characteristics are given in the study [2].

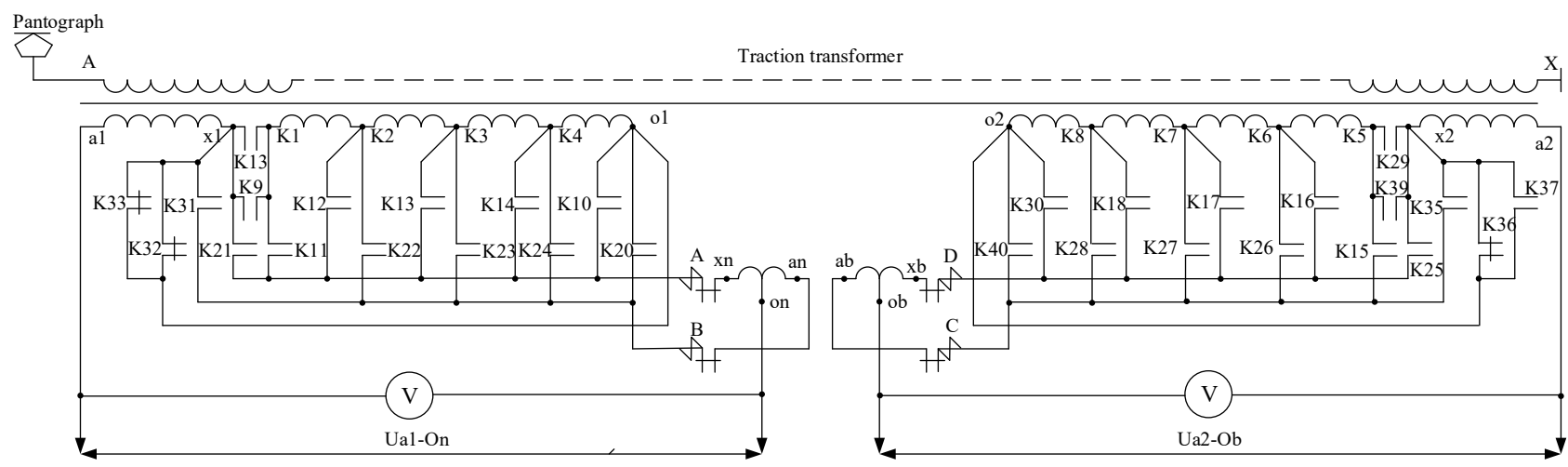

Fig. 1. Simplified diagram of the control circuits for the traction drive of the VL-80K electric locomotive:

$A-X$ - primary winding of the traction transformer; a1- $x 1$ - uncontrolled part of the secondary winding of the first section of the traction transformer $x 1-a 1$ - controlled part of the secondary winding of the first section of the traction transformer; $a 2-x 2$ - uncontrolled part of the secondary winding of the second section of the traction transformer; $x 2-02$ - controlled part of the secondary winding of the second section of the traction transformer; $K 1-K 40$ - contactors without arc extinguishing; $A, B, C, D$ - arc-extinguishing contactors 
The GEC power part contactors are implemented on Breaker elements. The algorithm for closing contactors according to the position of the driver's controller is implemented as a MATLAB Function. The inputs of the MATLAB Function block receive the position signal of the driver's controller $\langle p »$. At the outputs of this block for a given position of the driver's controller there will be a logical unit for contactors, which, in accordance with
Table 1 must be locked in this position. The rest of the outputs will be a logical zero. The voltage of the contact network on the simulation model is shown as a voltage source $U c$ with a frequency of $50 \mathrm{~Hz}$ and an amplitude of $25 \mathrm{kV}$. Voltmeters are designed to convert Specialized Power System signals to Simulink signals. Voltage oscillograms on the arms of the rectifier are displayed on the oscilloscope.

Circuit diagram of contactors EKG-8Zh (Russia)

Table 1

\begin{tabular}{|c|c|c|c|c|c|c|c|c|c|c|c|c|c|c|c|c|c|c|c|c|c|c|c|c|c|c|c|c|c|c|c|c|c|c|}
\hline \multirow{2}{*}{ Contactor } & \multicolumn{34}{|c|}{ Positions } \\
\hline & 0 & 1 & 2 & 3 & 4 & 5 & 6 & 7 & 8 & 9 & 10 & 11 & 12 & 13 & 14 & 15 & 16 & 17 & 18 & 19 & 20 & 21 & 22 & 23 & 24 & 25 & 26 & 27 & 28 & 29 & 30 & 31 & 32 & 33 \\
\hline 11 & 0 & 1 & 1 & 1 & 0 & 0 & 0 & 0 & 0 & 0 & 0 & 0 & 0 & 0 & 0 & 0 & 0 & 0 & 1 & 1 & 0 & 0 & 0 & 0 & 0 & 0 & 0 & 0 & 0 & 0 & 0 & 0 & 0 & 0 \\
\hline 22 & 0 & 0 & 1 & 1 & 1 & 1 & 0 & 0 & 0 & 0 & 0 & 0 & 0 & 0 & 0 & 0 & 0 & 0 & 1 & 1 & 1 & 1 & 0 & 0 & 0 & 0 & 0 & 0 & 0 & 0 & 0 & 0 & 0 & 0 \\
\hline 12 & 0 & 0 & 0 & 0 & 1 & 1 & 1 & 1 & 0 & 0 & 0 & 0 & 0 & 0 & 0 & 0 & 0 & 0 & 0 & 0 & 1 & 1 & 1 & 1 & 0 & 0 & 0 & 0 & 0 & 0 & 0 & 0 & 0 & 0 \\
\hline 23 & 0 & 0 & 0 & 0 & 0 & 0 & 1 & 1 & 1 & 1 & 0 & 0 & 0 & 0 & 0 & 0 & 0 & 0 & 0 & 0 & 0 & 0 & 1 & 1 & 1 & 1 & 0 & 0 & 0 & 0 & 0 & 0 & 0 & 0 \\
\hline 13 & 0 & 0 & 0 & 0 & 0 & 0 & 0 & 0 & 1 & 1 & 1 & 1 & 0 & 0 & 0 & 0 & 0 & 0 & 0 & 0 & 0 & 0 & 0 & 0 & 1 & 1 & 1 & 1 & 0 & 0 & 0 & 0 & 0 & 0 \\
\hline 24 & 0 & 0 & 0 & 0 & 0 & 0 & 0 & 0 & 0 & 0 & 1 & 1 & 1 & 1 & 0 & 0 & 0 & 0 & 0 & 0 & 0 & 0 & 0 & 0 & 0 & 0 & 1 & 1 & 1 & 1 & 0 & 0 & 0 & 0 \\
\hline 14 & 0 & 0 & 0 & 0 & 0 & 0 & 0 & 0 & 0 & 0 & 0 & 0 & 1 & 1 & 1 & 1 & 0 & 0 & 0 & 0 & 0 & 0 & 0 & 0 & 0 & 0 & 0 & 0 & 1 & 1 & 1 & 1 & 0 & 0 \\
\hline 20 & 0 & 0 & 0 & 0 & 0 & 0 & 0 & 0 & 0 & 0 & 0 & 0 & 0 & 0 & 1 & 1 & 1 & 1 & 0 & 0 & 0 & 0 & 0 & 0 & 0 & 0 & 0 & 0 & 0 & 0 & 1 & 1 & 1 & 0 \\
\hline 10 & 0 & 0 & 0 & 0 & 0 & 0 & 0 & 0 & 0 & 0 & 0 & 0 & 0 & 0 & 0 & 0 & 1 & 1 & 0 & 0 & 0 & 0 & 0 & 0 & 0 & 0 & 0 & 0 & 0 & 0 & 0 & 0 & 1 & 1 \\
\hline 15 & 0 & 1 & 1 & 1 & 1 & 0 & 0 & 0 & 0 & 0 & 0 & 0 & 0 & 0 & 0 & 0 & 0 & 0 & 1 & 1 & 1 & 0 & 0 & 0 & 0 & 0 & 0 & 0 & 0 & 0 & 0 & 0 & 0 & 0 \\
\hline 26 & 0 & 0 & 0 & 1 & 1 & 1 & 1 & 0 & 0 & 0 & 0 & 0 & 0 & 0 & 0 & 0 & 0 & 0 & 0 & 1 & 1 & 1 & 1 & 0 & 0 & 0 & 0 & 0 & 0 & 0 & 0 & 0 & 0 & 0 \\
\hline 16 & 0 & 0 & 0 & 0 & 0 & 1 & 1 & 1 & 1 & 0 & 0 & 0 & 0 & 0 & 0 & 0 & 0 & 0 & 0 & 0 & 0 & 1 & 1 & 1 & 1 & 0 & 0 & 0 & 0 & 0 & 0 & 0 & 0 & 0 \\
\hline 27 & 0 & 0 & 0 & 0 & 0 & 0 & 0 & 1 & 1 & 1 & 1 & 0 & 0 & 0 & 0 & 0 & 0 & 0 & 0 & 0 & 0 & 0 & 0 & 1 & 1 & 1 & 1 & 0 & 0 & 0 & 0 & 0 & 0 & 0 \\
\hline 17 & 0 & 0 & 0 & 0 & 0 & 0 & 0 & 0 & 0 & 1 & 1 & 1 & 1 & 0 & 0 & 0 & 0 & 0 & 0 & 0 & 0 & 0 & 0 & 0 & 0 & 1 & 1 & 1 & 1 & 0 & 0 & 0 & 0 & 0 \\
\hline 28 & 0 & 0 & 0 & 0 & 0 & 0 & 0 & 0 & 0 & 0 & 0 & 1 & 1 & 1 & 1 & 0 & 0 & 0 & 0 & 0 & 0 & 0 & 0 & م & 0 & 0 & 0 & 1 & 1 & 1 & 1 & 0 & 0 & 0 \\
\hline 18 & 0 & 0 & 0 & 0 & 0 & 0 & 0 & 0 & 0 & 0 & 0 & 0 & 0 & 1 & 1 & 1 & 1 & 0 & 0 & 0 & 0 & 0 & 0 & 0 & 0 & 0 & 0 & 0 & 0 & 1 & 1 & 1 & 1 & 0 \\
\hline 40 & 0 & 0 & 0 & 0 & 0 & 0 & 0 & 0 & 0 & 0 & 0 & 0 & 0 & 0 & 0 & 1 & 1 & 1 & 0 & 0 & 0 & 0 & 0 & 0 & 0 & 0 & 0 & 0 & 0 & 0 & 0 & 1 & 1 & 1 \\
\hline 30 & 1 & 0 & 0 & 0 & 0 & 0 & 0 & 0 & 0 & 0 & 0 & 0 & 0 & 0 & 0 & 0 & 0 & 1 & 0 & 0 & 0 & 0 & 0 & 0 & 0 & 0 & 0 & 0 & 0 & 0 & 0 & 0 & 0 & 1 \\
\hline 21 & 0 & 0 & 0 & 0 & 0 & 0 & 0 & 0 & 0 & 0 & 0 & 0 & 0 & 0 & 0 & 0 & 0 & 0 & 0 & 0 & 0 & 0 & 0 & 0 & 0 & 0 & 0 & 0 & 0 & 0 & 0 & 0 & 0 & 0 \\
\hline 25 & 0 & 0 & 0 & 0 & 0 & 0 & 0 & 0 & 0 & 0 & 0 & 0 & 0 & 0 & 0 & 0 & 0 & 0 & 0 & 0 & 0 & 0 & 0 & 0 & 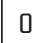 & 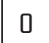 & 0 & 0 & 0 & 0 & 0 & 0 & 0 & 0 \\
\hline 9 & 0 & 0 & 0 & 0 & 0 & 0 & 0 & 0 & 0 & 0 & 0 & 0 & 0 & 0 & 0 & 0 & 0 & 0 & 1 & 1 & 1 & 1 & 1 & 1 & 1 & 1 & 1 & 1 & 1 & 1 & 1 & 1 & 1 & 1 \\
\hline 19 & 0 & 0 & 0 & 0 & 0 & 0 & 0 & 0 & 0 & 0 & 0 & 0 & 0 & 0 & 0 & 0 & 0 & 0 & 1 & 1 & 1 & 1 & 1 & 1 & 1 & 1 & 1 & 1 & 1 & 1 & 1 & 1 & 1 & 1 \\
\hline 32 & 1 & 1 & 1 & 1 & 1 & 1 & 1 & 1 & 1 & 1 & 1 & 1 & 1 & 1 & 1 & 1 & 1 & 1 & 0 & 0 & 0 & 0 & 0 & 0 & 0 & 0 & 0 & 0 & 0 & 0 & 0 & 0 & 0 & 0 \\
\hline 33 & 1 & 1 & 1 & 1 & 1 & 1 & 1 & 1 & 1 & 1 & 1 & 1 & 1 & 1 & 1 & 1 & 1 & 1 & 0 & 0 & 0 & 0 & 0 & 0 & 0 & 0 & 0 & 0 & 0 & 0 & 0 & 0 & 0 & 0 \\
\hline 29 & 0 & 0 & 0 & 0 & 0 & 0 & 0 & 0 & 0 & 0 & 0 & 0 & 0 & 0 & 0 & 0 & 0 & 0 & 1 & 1 & 1 & 1 & 1 & 1 & 1 & 1 & 1 & 1 & 1 & 1 & 1 & 1 & 1 & 0 \\
\hline 39 & 0 & 0 & 0 & 0 & 0 & 0 & 0 & 0 & 0 & 0 & 0 & 0 & 0 & 0 & 0 & 0 & 0 & 0 & 1 & 1 & 1 & 1 & 1 & 1 & 1 & 1 & 1 & 1 & 1 & 1 & 1 & 1 & 1 & 0 \\
\hline 36 & 0 & 1 & 1 & 1 & 1 & 1 & 1 & 1 & 1 & 1 & 1 & 1 & 1 & 1 & 1 & 1 & 1 & 1 & 0 & 0 & 0 & 0 & 0 & 0 & 0 & 0 & 0 & 0 & 0 & 0 & 0 & 0 & 0 & 0 \\
\hline 37 & 0 & 1 & 1 & 1 & 1 & 1 & 1 & 1 & 1 & 1 & 1 & 1 & 1 & 1 & 1 & 1 & 1 & 1 & 0 & 0 & 0 & 0 & 0 & 0 & 0 & 0 & 0 & 0 & 0 & 0 & 0 & 0 & 0 & 0 \\
\hline 31 & 0 & 0 & 0 & 0 & 0 & 0 & 0 & 0 & 0 & 0 & 0 & 0 & 0 & 0 & 0 & 0 & 0 & 0 & 0 & 0 & 0 & 0 & 0 & 0 & 0 & 0 & 0 & 0 & 0 & 0 & 0 & 0 & 0 & 0 \\
\hline & 0 & 0 & 10 & 0 & 0 & & 10 & 0 & 0 & & त & 0 & ? & ח & 0 & [ & & & & [ & 0 & 0 & 10 & U & 0 & 0 & 0 & 0 & 0 & 0 & 0 & 0 & 0 & 0 \\
\hline
\end{tabular}




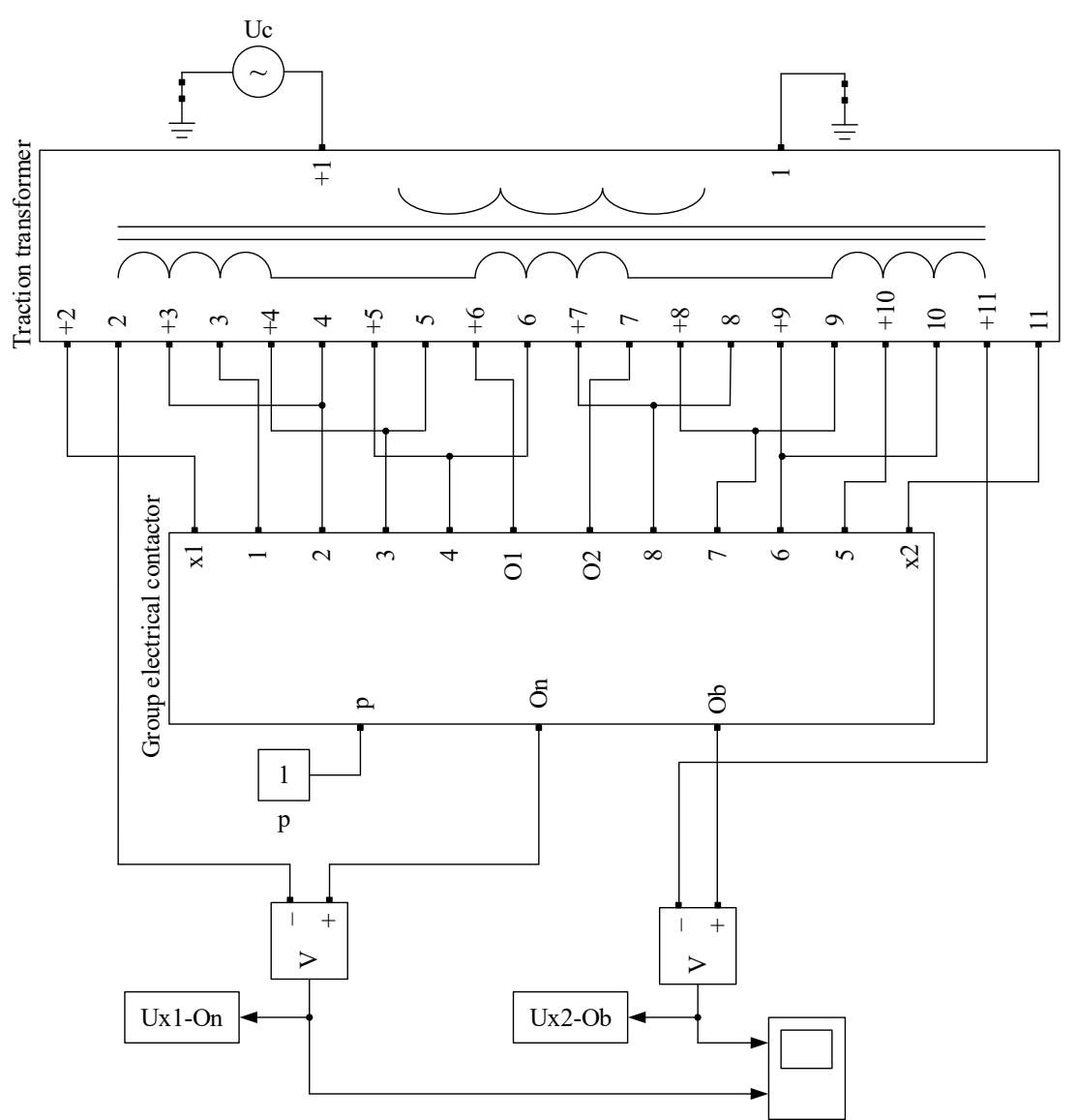

Fig. 2. Simulation model of the control system for the traction drive of the electric locomotive VL-80K

\section{Research results and discussion}

The experimental data were taken on the VL-80K electric locomotive No. 599 of section A on the DarnytsiaMyronivka section (Ukraine) on September 25, 2021. The measurement results are listed in Table 2.

In the simulation model, voltages were removed by changing the position of the controller to the driver from 1 to 33. Fig. 3 and Fig. 4 show the voltage waveforms on the arms of the rectifier for the even and odd positions (19th and 20th positions). It can be seen from them that for an even position, the voltages on the arms of the rectifier are the same, for an odd position they are different. Therefore, in Table 2, both for the experimental data and for the data obtained as a result of simulation, the voltage values for both arms of the rectifier installation are entered.

For each position, the error in determining the voltage on the arms of the rectifier installation is calculated using the formula:

$$
\gamma=\frac{U_{m o d}-U_{e x}}{U_{m o d}} \cdot 100 \%,
$$

where $U_{\text {mod }}$ - voltage value on the arms of the rectifier installation, obtained as a result of simulation; $U_{e x}$ - experimental value of the voltage on the arms of the rectifier installation.

The calculation results are listed in Table 2.

As can be seen from Table 2, the errors in determining the voltage on the arms of the rectifier installation do not exceed $5 \%$. In addition, the 28 th position of the position of the driver's controller corresponds to the nominal mode of operation of the traction drive of the electric locomotive. Rated voltage value for electric locomotives of this series is $U_{\text {nom }}=950 \mathrm{~V}[26]$. The error in determining the voltage of this position during the experiment was $0.5 \%$, and during the simulation - $3.79 \%$.

In other words, the developed model of the control system for the traction drive of the VL-80K electric locomotive makes it possible to obtain voltages on the arms of the rectifier installation with a high degree of reliability and is applicable when modeling the traction drive of an electric locomotive of this series.

When simulating a traction drive, the intensity generator can be organized programmatically using the MATLAB Function instead of manually setting the $\ll p »$ positions, as shown in the model (Fig. 2).

During the study, two assumptions were put forward that limit the application of the developed model.

The first assumption is that during the experimental measurements, the instantaneous values of the voltage on the arms of the rectifier installation were converted into amplitude values. When modeling, operations were performed with amplitude values of voltages. This approach is related to the fact that in the reference book the corresponding voltage values are given in amplitude values. When using the proposed control system model to implement the traction drive model as a whole, one should operate with instantaneous voltage values.

The second assumption is that the implementation of the ECG operation algorithm when modeling at positions 31-33 did not take into account the weakening of 
the excitation magnetic field. This factor is related to the fact that it is more convenient to implement the algorithm for weakening the excitation magnetic field when simulating a traction motor.

The further development of this study can be the task of operating modes of the electric locomotive. This can be achieved by replacing the model of the manual po- sition setting block «p» with a speed intensity setting block, where the change in positions will be set by the corresponding time function. Thus, it will be possible to set the starting mode, traction mode, braking. The condition for setting the intensity of speed change may be the implementation of the corresponding traction and braking characteristics.

The value of the voltage at the output of the EKG-8Zh

Table 2

\begin{tabular}{|c|c|c|c|c|c|c|}
\hline \multirow{2}{*}{$\begin{array}{l}\text { Position No. of the } \\
\text { driver's controller }\end{array}$} & \multicolumn{2}{|c|}{$U_{a 1-D_{n},} \mathrm{~V}$} & \multirow{2}{*}{$\gamma_{1} \%$} & \multicolumn{2}{|c|}{$U_{a 2-a b}, \mathrm{~V}$} & \multirow{2}{*}{$\gamma, \%$} \\
\hline & Model & Experiment & & Model & Experiment & \\
\hline 1 & 414.9 & 395 & 4.8 & 819.6 & 780 & 4.83 \\
\hline 2 & 47.94 & 45 & 6.13 & 47.94 & 45 & 6.13 \\
\hline 3 & 120.4 & 115 & 4.49 & 47.94 & 45 & 6.13 \\
\hline 4 & 120.4 & 115 & 4.49 & 120.4 & 115 & 4.49 \\
\hline 5 & 192.8 & 185 & 4.05 & 120.4 & 115 & 4.49 \\
\hline 6 & 192.8 & 185 & 4.05 & 192.8 & 185 & 4.05 \\
\hline 7 & 266.1 & 255 & 4.17 & 192.8 & 185 & 4.05 \\
\hline 8 & 266.1 & 255 & 4.17 & 266.1 & 255 & 4.17 \\
\hline 9 & 337.5 & 325 & 3.7 & 266.1 & 255 & 4.17 \\
\hline 10 & 337.5 & 325 & 3.7 & 337.5 & 325 & 3.7 \\
\hline 11 & 409.8 & 395 & 3.61 & 337.5 & 325 & 3.7 \\
\hline 12 & 409.8 & 395 & 3.61 & 409.8 & 395 & 3.61 \\
\hline 13 & 482.3 & 465 & 3.59 & 409.8 & 395 & 3.61 \\
\hline 14 & 482.3 & 465 & 3.59 & 482.3 & 465 & 3.59 \\
\hline 15 & 555.1 & 535 & 3.62 & 482.3 & 465 & 3.59 \\
\hline 16 & 555.1 & 535 & 3.62 & 555.1 & 535 & 3.62 \\
\hline 17 & 626.2 & 605 & 3.39 & 555.1 & 535 & 3.62 \\
\hline 18 & 626.2 & 605 & 3.39 & 626.2 & 605 & 3.39 \\
\hline 19 & 697.6 & 675 & 3.24 & 626.2 & 605 & 3.39 \\
\hline 20 & 697.6 & 675 & 3.24 & 697.6 & 675 & 3.24 \\
\hline 21 & 772.1 & 745 & 3.51 & 697.6 & 675 & 3.24 \\
\hline 22 & 772.1 & 745 & 3.51 & 772.1 & 745 & 3.51 \\
\hline 23 & 841.5 & 815 & 3.15 & 772.1 & 745 & 3.51 \\
\hline 24 & 841.5 & 815 & 3.15 & 841.5 & 815 & 3.15 \\
\hline 25 & 916.8 & 885 & 3.47 & 841.5 & 815 & 3.15 \\
\hline 26 & 916.8 & 885 & 3.47 & 916.8 & 885 & 3.47 \\
\hline 27 & 986 & 955 & 3.14 & 916.8 & 885 & 3.47 \\
\hline 28 & 986 & 955 & 3.14 & 986 & 955 & 3.14 \\
\hline 29 & 1062 & 1025 & 3.48 & 986 & 955 & 3.14 \\
\hline 30 & 1062 & 1025 & 3.48 & 1062 & 1025 & 3.48 \\
\hline 31 & 1130 & 1095 & 3.1 & 1062 & 1025 & 3.48 \\
\hline 32 & 1130 & 1095 & 3.15 & 1130 & 1095 & 3.1 \\
\hline 33 & 1202 & 1165 & 3.08 & 1130 & 1095 & 3.1 \\
\hline
\end{tabular}




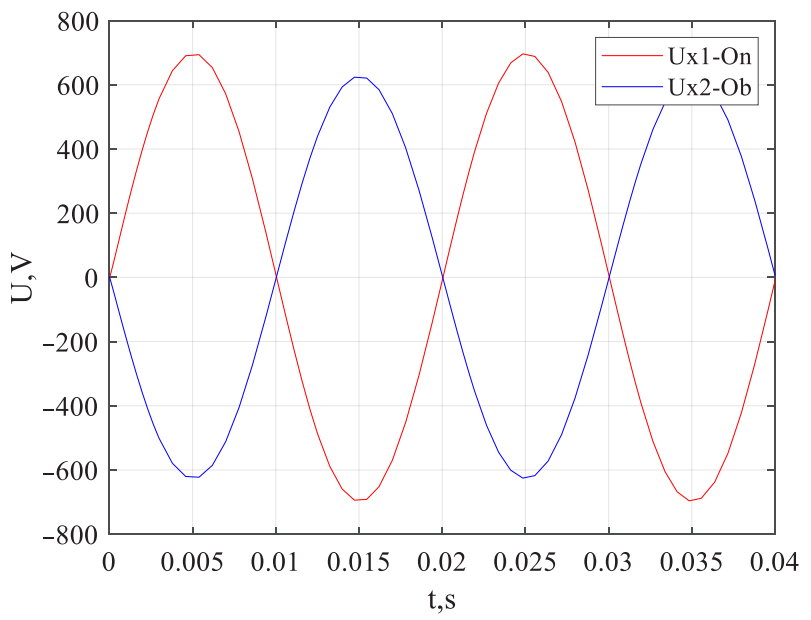

Fig. 3. Oscillograms of voltages on the arms of the rectifier installation for the 19th position of the driver's controller

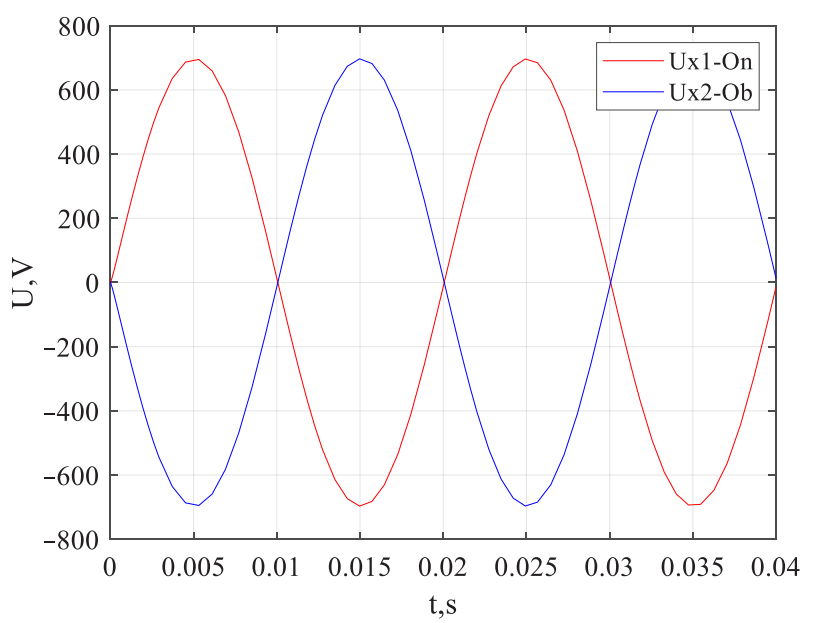

Fig. 4. Oscillograms of voltages on the arms of the rectifier installation for the 20th position of the driver's contraller

\section{Conclusions}

A scheme for measuring on the arms of the rectifier installation of an electric locomotive of the VL-80K series is proposed.

Based on the proposed measurement scheme in the MATLAB software environment, a simulation model of the traction drive control system for an electric locomotive of the VL-80K series was developed.

On the basis of the proposed measurement scheme, the values of voltages on the arms of the rectifier installation of the VL-80K electric locomotive were obtained experimentally and as a result of modeling the technique. The results of the voltage values on the arms of the rectifier installation obtained experimentally and as a result of modeling for the nominal mode are compared. Comparison of the results showed that the error in determining the voltages as a result of the experiment was $0.5 \%$, as a result of modeling - $3.79 \%$. Voltage determination errors for all other modes did not exceed $5 \%$.

\section{References}

1. Kulinich, Y. M., Shukharev, S. A., Drogolov, D. Y. (2019) Simulation of the pulsating current traction motor. Vestnik of the Railway Research Institute, 78 (5), 313-319. doi: http:// doi.org/10.21780/2223-9731-2019-78-5-319
2. Hulak, S. O., Yermolenko, E. K. (2016). Model systemy Tiahova pidstantsiia-kontaktna merezha-tiahovyi pryvid elektrovoza serii VL-80 T, K. Zbirnyk naukovykh prats Derzhavnoho ekonomiko tekhnolohichnoho universytetu transportu. Seriia: Transportni systemy i tekhnolohii, 28, 99-109.

3. Goolak, S., Tkachenko, V., Sapronova, S., Spivak, O., Riabov, I., Ostroverkh, O. (2021). Determination of inductances for pulsating current traction motor. Technology Audit and Production Reserves, 2 (1 (58)), 40-43. doi: http://doi.org/10.15587/27065448.2021.229217

4. Litovchenko, V. V., Nazarov, D. V., Sharov, V. A. (2020). Simulation Model of a Direct-Current Electric Locomotive with Commutator Traction Motors. Russian Electrical Engineering 91 (1), 69-76. doi: http://doi.org/10.3103/s1068371220010071

5. Antipin, D. Y., Vorobiev, V. I., Izmerov, O. V. (2019). Possibilities of modernization of wheel motor blocks of locomotives IOP Conference Series: Earth and Environmental Science, 378, 012004. doi: http://doi.org/10.1088/1755-1315/378/1/012004

6. Islam, J., Nategh, S., Moghaddam, R. R., Boglietti, A. (2020) Different Traction Motor Topologies Used in E-mobility: Part I: Solutions without magnet. 2020 International Conference on Electrical Machines (ICEM), 1, 131-137. doi: http://doi.org/ 10.1109/icem49940.2020.9270776

7. Goolak, S., Sapronova, S., Tkachenko, V., Riabov, I., Batrak, Y. (2020). Improvement of the model of power losses in the pulsed current traction motor in an electric locomotive. Eastern-European Journal of Enterprise Technologies, 6 (5 (108)), 38-46. doi: http://doi.org/10.15587/1729-4061.2020.218542

8. Popescu, M., Goss, J., Staton, D. A., Hawkins, D., Chong, Y. C., Boglietti, A. (2018). Electrical Vehicles - Practical Solutions for Power Traction Motor Systems. IEEE Transactions on Industry Applications, 54 (3), 2751-2762. doi: http://doi.org/10.1109/ tia.2018.2792459

9. Goolak, S., Riabov, I., Tkachenko, V., Sapronova, S., Rubanik, I (2021). Model of pulsating current traction motor taking into consideration magnetic losses in steel. Electrical Engineering $\mathcal{E}$ Electromechanics, 6, 11-17. doi: http://doi.org/10.20998/ 2074-272x.2021.6.02

10. Evseev, V. Y., Savos'kin, A. N. (2020). A Mathematical Model of a Collector Traction Motor with Separate Consideration of Eddy Currents of the Main and Additional Poles. Russian Electrical Engineering, 91 (9), 557-563. doi: http://doi.org/ $10.3103 / \mathrm{s} 1068371220090047$

11. Ouamara, D., Dubas, F. (2019). Permanent-Magnet EddyCurrent Losses: A Global Revision of Calculation and Analysis. Mathematical and Computational Applications, 24 (3), 67. doi: http://doi.org/10.3390/mca24030067

12. Sano, H., Narita, K., Schneider, N., Semba, K., Tani, K., Yamada, T, Akaki, R. (2020). Loss Analysis of a Permanent Magnet Traction Motor in a Finite Element Analysis based Efficiency Map. 2020 International Conference on Electrical Machines (ICEM), 2301-2306. doi: http://doi.org/10.1109/icem49940.2020.9270713

13. Zhou, Z., Chen, Z., Spiryagin, M., Wolfs, P., Wu, Q., Zhai, W., Cole, C. (2021). Dynamic performance of locomotive electric drive system under excitation from gear transmission and wheelrail interaction. Vehicle System Dynamics, 1-23. doi: http:/ doi.org/10.1080/00423114.2021.1876887

14. Goolak, S., Sapronova, S., Tkachenko, V., Riabov, Ie., Overianova, L., Yeritsyan, B. (2021). Mathematical model of mechanical subsystem of traction electric drive of an electric locomotive. Naukovi Visti Dalivskogo Universitetu, 21. Available at: http:// nvdu.snu.edu.ua/wp-content/uploads/2021/10/2021_21_14.pdf

15. Galiev, I. I., Minzhasarov, M. K., Lipunov, D. V. (2019). Mathematical Model of Traction Rolling Stock Oscillations for the Assessment of Dynamic Loading of Its Components. International Scientific Siberian Transport Forum. Cham: Springer, 443-454. doi: http://doi.org/10.1007/978-3-030-37916-2 43

16. Ozulu, A. B., Krasilnikov, O. O., Bochevar, O. G. (2019). Research of modernized electric drive electric locomotiv VL-80. Bulletin of the National Technical University «KhPI». Ser.: Technique and Electrophysics of High Voltage, 18, 51-54. Available at: http://repository.kpi.kharkov.ua/handle/KhPI-Press/42733 
17. Aissa, B., Hamza, T., Yacine, G., Mohamed, N. (2021). Impact of sensorless neural direct torque control in a fuel cell traction system. International Journal of Electrical and Computer Engineering (IJECE), 11 (4), 2725-2732. doi: http://doi.org/10.11591/ ijece.v11i4.pp2725-2732

18. Hassan, M. M., Shaikh, M. S., Jadoon, H. U. K., Atif, M. R., Sardar, M. U. (2020). Dynamic Modeling and Vector Control of AC Induction Traction Motor in China Railway. Sukkur IBA Journal of Emerging Technologies, 3 (2), 115-125. doi: http:// doi.org/10.30537/sjet.v3i2.622

19. Wang, H., Liu, Y., Ge, X. (2018). Sliding-mode observer-based speed-sensorless vector control of linear induction motor with a parallel secondary resistance online identification. IET Electric Power Applications, 12 (8), 1215-1224. doi: http://doi.org/ 10.1049/iet-epa.2018.0049

20. Havryliuk, V. (2018). Modelling of the return traction current harmonics distribution in rails for AC electric railway system. 2018 International Symposium on Electromagnetic Compatibility (EMC EUROPE), 251-254. doi: http://doi.org/10.1109/ emceurope.2018.8485160

21. Titova, T. S., Evstaf'ev, A. M., Nikitin, V. V. (2018). The Use of Energy Storages to Increase the Energy Effectiveness of Traction Rolling Stock. Russian Electrical Engineering, 89 (10), 576-580. doi: http://doi.org/10.3103/s1068371218100097

22. Evstaf'ev, A. M., Kiryushin, D. E., Nikitin, V. V., Pudovikov, O. E (2021). Improvement of Traction Rolling Stock Based on Modern Energy-Saving Technologies. Russian Electrical Engineering, 92 (2), 59-62. doi: http://doi.org/10.3103/s1068371221020036

23. Nikitenko, A. (2018). Electromagnetic processes of charging of on-board supercapacitor storage system during the regenerative braking mode of DC electric rolling stock with series-wound DC motors. MATEC Web of Conferences, 180, 02007. doi: http:// doi.org/10.1051/matecconf/201818002007

24. Alturbeh, H., Stow, J., Lawton, A. (2018). Low Adhesion Braking Dynamic Optimisation for Rolling Stock (LABRADOR) Simulation Model. 8th International Conference on Railway Engineering (ICRE 2018). doi: http://doi.org/10.1049/cp.2018.0050
25. Burkov, A. T., Valinsky, O. S., Evstaf'ev, A. M., Maznev, A. S., Tretyakov, A. V. (2019). Modern Locomotive Traction Drive Control Systems. Russian Electrical Engineering, 90 (10), 692-695. doi: http://doi.org/10.3103/s106837121910002x

26. Elektrovoz VL-80k. Rukovodstvo po ekspluatatsii (1978). Moscow: Transport, 452.

$\triangle$ Sergey Goolak, PhD, Department of Electromechanics and Railway Rolling Stock, State University of Infrastructure and Technology, Kyiv, Ukraine, e-mail: sgoolak@gmail.com, ORCID: https://orcid.org/ 0000-0002-2294-5676

Eduard Yermolenko, Postgraduate Student, Department of Electromechanics and Railway Rolling Stock, State University of Infrastructure and Technology, Kyiv, Ukraine, ORCID: https://orcid.org/ 0000-0003-2832-2047

Viktor Tkachenko, Doctor of Technical Sciences, Professor, Head of Department of Electromechanics and Railway Rolling Stock, State University of Infrastructure and Technology, Kyiv, Ukraine, ORCID: https://orcid.org/0000-0002-5513-2436

Svitlana Sapronova, Doctor of Technical Sciences, Professor, Department of Cars and Carriage Facilities, State University of Infrastructure and Technology, Kyiv, Ukraine, ORCID: http://orcid.org/ 0000-0002-1482-1665

Viktor Yurchenko, Postgraduate Student, Department of Electromechanics and Railway Rolling Stock, State University of Infrastructure and Technology, Kyiv, Ukraine, ORCID: https://orcid.org/ 0000-0002-5900-874X

$\triangle$ Corresponding author 